Sensors and Transducers 
Other Macmillan books of related interest

J. C. Cluley, Transducers for Microprocessor Systems

B. A. Gregory, An Introduction to Electrical Instrumentation and Measurement Systems

M. J. Usher, Information Theory for Information Technologists 


\title{
Sensors and Transducers
}

\author{
M.J. USHER
}

Department of Cybernetics

University of Reading

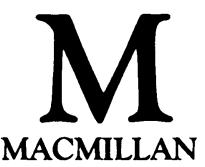


(C) M. J. Usher 1985

Softcover reprint of the hardcover 1st edition 1985 978-0-333-38709-2

All rights reserved. No reproduction, copy or transmission of this publication may be made without written permission.

No paragraph of this publication may be reproduced, copied or transmitted save with written permission or in accordance with the provisions of the Copyright Act 1956 (as amended).

Any person who does any unauthorised act in relation to this publication may be liable to criminal prosecution and civil claims for damages.

First published 1985

Published by

Higher and Further Education Division MACMILLAN PUBLISHERS LTD

Houndmills, Basingstoke, Hampshire RG21 LXS

and London

Companies and representatives

throughout the world

British Library Cataloguing in Publication Data

Usher, M. J.

Sensors and transducers.

1. Detectors 2. Transducers

I. Title

$620^{\prime} .0044$ TK7872.D/

ISBN 978-0-333-38710-8 ISBN 978-1-349-18052-3 (eBook)

DOI 10.1007/978-1-349-18052-3 


\section{Contents}

Preface

viii

Acknowledgements

1 Introduction

1.1 Analogue and digital quantities

1.2 Classification of sensing devices

1.3 Sensors and transducers

1.4 Types of transducer

3

1.5 Transducer parameters

4

1.6 Exercises on chapter 1

2 Analogies between Systems 9

$\begin{array}{lll}2.1 & \text { Analogies } & 9\end{array}$

$\begin{array}{ll}2.2 & \text { Mechanical and electrical systems }\end{array}$

$\begin{array}{ll}2.3 & \text { Fluid systems } \\ 2.4 & 16\end{array}$

$\begin{array}{lll}2.4 & \text { Thermal systems } & 18\end{array}$

2.5 Other systems: radiant, magnetic, chemical 19

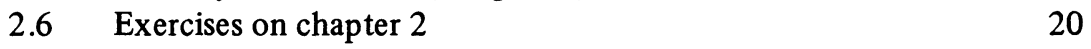

3 The Physical Effects available for Use in Transducers 23

$\begin{array}{lll}3.1 & \text { Representation of transducers } & 23\end{array}$

$\begin{array}{lll}3.2 & \text { Self-generators } & 24\end{array}$

$\begin{array}{lll}3.3 & \text { Modulators } & 32\end{array}$

$\begin{array}{lll}3.4 & \text { Modifiers } & 40\end{array}$

3.5 Exercises on chapter $3 \quad 41$ 
4 Transducer Bridges and Amplifiers

$\begin{array}{lll}4.1 & \text { Transducer bridges } & 43 \\ 4.2 & \text { Transducer amplifiers } & 46 \\ 4.3 & \text { Exercises on chapter } 4 & 49\end{array}$

$5 \quad$ Basic Transducers for Length $\quad 51$

5.1 Classification of length transducers 51

5.2 Displacement transducers $\quad 52$

$\begin{array}{lll}5.3 & \text { Velocity transducers } & 69\end{array}$

$\begin{array}{lll}5.4 & \text { Strain transducers } & 72\end{array}$

$\begin{array}{lll}5.5 & \text { Exercises on chapter } 5 & 78\end{array}$

6 Basic Transducers for Temperature $\quad 81$

$\begin{array}{lll}6.1 & \text { Scale of temperature } & 81\end{array}$

$\begin{array}{ll}6.2 \text { Temperature transducers } & 82\end{array}$

$\begin{array}{lll}6.3 & \text { Exercises on chapter } 6 & 88\end{array}$

7 Basic Transducers for Radiation $\quad 89$

$\begin{array}{lll}7.1 & \text { Classification of photodetectors } & 89\end{array}$

$\begin{array}{ll}7.2 \text { Thermal photodetectors } & 90\end{array}$

$\begin{array}{llr}7.3 & \text { Photon detectors } & 93\end{array}$

$\begin{array}{llr}7.4 & \text { Exercises on chapter } 7 & 101\end{array}$

8 Other Transducers $\quad 103$

$\begin{array}{ll}\text { 8.1 Acceleration transducers } & 103\end{array}$

$\begin{array}{lll}8.2 & \text { Force transducers } & 106\end{array}$

$\begin{array}{ll}\text { 8.3 Pressure transducers } & 110\end{array}$

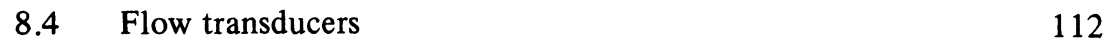

$\begin{array}{lll}\text { 8.5 Exercises on chapter 8 } & 117\end{array}$

9 Recent Developments in Transducers $\quad 121$

$\begin{array}{lll}9.1 & \text { Optical-fibre transducers } & 121\end{array}$

$\begin{array}{lll}9.2 & \text { Resonator sensors } & 125\end{array}$

$\begin{array}{lll}9.3 & \text { Solid-state transducers } & 128\end{array}$

$\begin{array}{lll}9.4 & \text { Smart sensors } & 133\end{array}$

$\begin{array}{ll}9.5 & \text { Exercises on chapter } 9\end{array}$

10 Solutions to Exercises 135

$\begin{array}{lll}10.1 & \text { Solutions to exercises on chapter } 1 & 135\end{array}$

10.2 Solutions to exercises on chapter 2 136

$\begin{array}{lll}10.3 & \text { Solutions to exercises on chapter } 3 & 139\end{array}$

$\begin{array}{lll}10.4 & \text { Solutions to exercises on chapter 4 } & 140\end{array}$

$\begin{array}{lll}10.5 & \text { Solutions to exercises on chapter } 5 & 141\end{array}$

$\begin{array}{lll}10.6 & \text { Solutions to exercises on chapter } 6 & 145\end{array}$ 
10.7 Solutions to exercises on chapter 7

10.8 Solutions to exercises on chapter 8

149

10.9 Solutions to exercises on chapter 9

155

References and Bibliography 158

$\begin{array}{ll}\text { Index } & 161\end{array}$ 


\section{Preface}

Most quantities that we need to measure are inherently analogue. There is nothing very digital about a length or a temperature and, even though light may be considered to consist of photons, most measurements involve such large numbers that the process is effectively analogue. Our own senses are analogue, so it is hardly surprising that the vast majority of physical sensors are analogue as well. It is only since the developments in microprocessor technology that digital transducers have become important; however, they still have to measure analogue quantities, and most digital transducers therefore employ exactly the same physical principles as their analogue counterparts.

The words 'sensor' and 'transducer' are widely used in referring to sensing devices, the former having gained in popularity over the latter in recent years. This is a pity because 'transducer' stresses the change of form of energy basic to the sensing process and leads to an elegant and powerful classification of devices. The word 'transducer' is used here when considering a complete sensing device, in which a change of form of energy always occurs, the word 'sensor' being reserved for devices that are not energy-converting, such as a thermistor which simply changes its resistance in response to temperature.

The aim of the book is to provide an integrated account of the principles and properties of the most important types of physical transducer. The first chapter discusses the types of physical energy and the corresponding signals, and identifies three basic types of transducer. A synthesis of the subject is attempted in chapter 2 , by describing the analogies that exist between different physical systems. Chapter 3 starts with a three-dimensional representation of all possible transducers and goes on to consider the basic physical mechanisms available for transduction. Chapter 4 develops the relevant expressions for amplifiers and transducer bridges that are required before the detailed descriptions of the basic transducers for length, temperature and radiation can be given in chapters 5,6 and 7. For each of these quantities the physical background and 
standards are explained, followed by both a theoretical treatment of the basic transducers and a description of their practical design and application. Chapter 8 includes a description of the application of the basic transducers to several fields of measurement such as acceleration, force, pressure and flow, and the final chapter reviews some of the most recent developments in the transducer field, such as optical-fibre sensors, resonator sensors, solid-state devices, and smart sensors.

The book is specifically about transducers rather than measurement systems, and provides an integrated and comprehensive coverage of presently available transducers and recent developments. The classification of transducers, based on energy conversion, automatically encompasses both 'analogue' and 'digital' devices, which are seen to be simply different ways of using a particular physical principle. The book is intended as an undergraduate text for first year students in engineering, physics and information technology. 


\section{Acknowledgements}

The author wishes to thank Professor Fellgett, Head of the Department of Cybernetics at Reading University, for his suggestions and encouragement regarding the lecture courses on which the book is based, and his wife and Mrs Jean Wild, who did the typing (and corrections). He also acknowledges the assistance of the many Cybernetics students who acted as willing guinea-pigs* during the development of the lecture course.

*Guinea-pigs are nocturnal animals that mostly sleep during the day. 